\title{
SPEECH-LANGUAGE PATHOLOGY AND AUDIOLOGY: TRANSFORMATION IN TEACHING, RESEARCH AND SERVICE DELIVERY
}

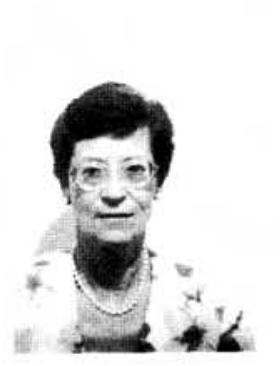

\author{
Isabel C Uys, D.Phil
}

Professor:

Dept. Communication Pathology

University of Pretoria

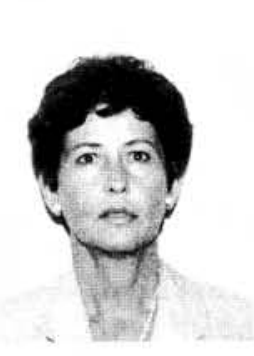

\section{OPSOMMING}

Die doel van hierdie artikel is om transformasie in kommunikasiepatologie voor te hou. Die redes vir radikale verandering word gevind in die behoeftes van die kommunikatiefgestremde in Suid-Afrika. As gevolg van die tradisionele westerse model wat aangehang is in die verlede blyk dit dat spraak-taalterapeutiese en oudiologiese dienste nie toeganklik, en selfs toepaslik was vir Suid-Afrikaanse omstandighede nie. Die transformasieproses het ingrypende implikasies vir onderrig, navorsing en dienslewering en binne die raamwerk van ' $n$ totale herstrukturering van die beroep, word modelle vir transformasie op hierdie drie vlakke voorgestel.

\begin{abstract}
This article aims at a presentation of transformation in communication pathology. The reasons for radical change can be found in the needs of the communicatively disabled in South Africa. Due to the adherence to the traditional western model in the past, it has become clear that speech-language and audiological services have not been available, or even applicable in the South African context. The transformation process has radical implications for teaching, research and service delivery. Within this framework of total restructuring of the profession, models for transformation at these three levels, are presented.
\end{abstract}

\section{INTRODUCTION}

Since the introduction of the profession and teaching in speech-language therapy and audiology in this country in the early 1930's it has been characterised by unprecedented development, expansion and restructuring. On the one hand this tendency can be attributed to the explosion of knowledge, especially in the sciences of human behaviour, linguistics, medicine, and technology, whilst on the other, the search for relevancy, efficacy, and efficiency played an important role.

It was already during 1966 that Pienaar (Rieber \& Brubaker, 1996:600-601), the Father of Speech-Language Pathology and Audiology in South Africa wrote: "A young country, with a comparatively small percentage of wage earners, keen on expansion in every sphere of life, with no endowments and handicapped by a lack of funds, has had to march forward on faith, hope and charity and its youthful idealism. We are jealous of our standards of training, of research and therapeutics ... We realize the vastness of the field still lying fallow; the great task still ahead of us to cater to the needs of the whole population of South Africa and through South Africa for the whole of the awakening Southern Africa."

Unfortunately, up till now the development was based on reformation, still adhering to the traditional Western, or Medical Model, while what is needed is transformation - a very basic change in character, form, appearance, and even disposition. Change in training and service delivery, based on traditional premises, can never cater for the needs of the communicatively disabled in this country.

A paradigm shift is necessary, i.e. the realisation that the future depends on new thinking and not on rethinking, underpins the Model for Transformation put forward in this article. Although conceived as a model for teaching, research and service delivery for the profession of SpeechLanguage Pathology and Audiology, this model could well be applied to any of the other health professions.

\section{THE NEED FOR TRANSFORMATION}

The need for speech-language therapy and audiology services is constantly underestimated, primarily due to ignorance about the prevalence of human communication disorders/disabilities and the scope of the profession. This is inexplicable, as at least $10 \%$ of the total population present with some form of speech, language or hearing disorder of such magnitude that it impedes the person's ability to communicate (Disability in the Republic of South Africa, volume 10,1987$)$. With the high premium placed on communication today, the consequences of a disorder which interferes with communication, attracts negative attention, or causes the speaker to be maladjusted, can be devastating. As Beukelman and Garrett (1988:104) so aptly puts it: "Speechlessness is not a loss of life, but a loss of access to life". 
With the improvement in medical technology many lives are saved, but this leads to a vast increase in the number of handicapped and disabled people, many of whom are communicatively impaired. Often the communicatively impaired become socially, culturally, emotionally and intellectually handicapped, and remain a burden to the community unless they are rehabilitated and reintegrated in society.

The question can now be asked why a profession devoted to serving the communication impaired, a profession that has been practised in this country with great efficiency for about six decades, should be transformed? The answer is clear: The unique needs for health services in South Africa have not been met at all levels. The commission investigating disability in the Republic found that "...existing services are distributed unevenly in the development regions. There are in fact development regions which completely lack certain basic services for the disabled. It is further noticed that in many respects there is an unequal distribution of services among the various population groups... The complete view that is obtained at the macrolevel is that services are mainly limited to the metropolitan areas and that a significant percentage of disabled people have little or no access to the existing services. It is, therefore, selfevident that in a programme for the upgrading of services, the horisontal distribution of services must be examined before generally vertical extension of services can be considered" (Disability in the Republic of South Africa, Main Report 1, 1987:14).

These findings are also to a large extent applicable to the field of speech-language therapy and audiology. Within the framework of the Western Model, which is implemented with great success in the developed western countries, many of the health professions are regarded as a luxury, available and accessible only to the rich. Therapists deliver services on a one-to-one basis in clinical settings, while most of the clients live in rural communities, far from these clinics, schools and hospitals. There is a dire need to bring the service to the clients, instead of bringing the clients to the service.

Another premise inherent in the Western Model reflects on the nature of the teaching and service, namely that it is disorder-orientated. The implication is that therapists are trained to identify, diagnose and treat specific communication disorders. Taking into account the needs of a developing country, the scope of the profession must be extended to include aspects such as public and continuing education programmes, prevention, consultation and early intervention. A paradigm shift towards a function-orientation is needed. The multilingual nature of society has a particular impact on the field of communication pathology. While in other health professions language is a medium for rehabilitation, in this profession language is both the medium and the goal. It is an unfortunate fact that there are only a few African language mother-tongue speakers qualified as speechlanguage therapists and audiologists (SAMDC, 1995). This need should be addressed as a priority in order to institute and deliver accessible, affordable, efficient and effective services to all population groups.

Together with the above problem, the personpower shortage in this profession should be addressed. Calculated at about 500 clients per professional each year, it is estimated that with the projected population growth, the number of professionally trained speech-language therapists and audiologists required in the year 2000 will be in the order of 10000 . Currently there are only 1024 registered professionals, with an average of less that 100 qualifying each year (Uys, 1996). One of the ways in which to address this shortage is to shift from an institution-based to a community-based approach, as envisaged by a primary health care orientation. According to traditional thinking graduate therapists are too highly trained to carry out primary health care. This is a fallacy. Within the new paradigm it becomes clear that the performance of primary intervention services is a specialisation in its own right. Health care workers, in this case communication pathology professionals, should be trained differently, allowing for laddering in teaching programmes. This implies the structuring of training programmes in such a way that trainees will have access to a natural progression from certificate programmes, through the diploma level to graduate programmes and specialization. Added to this, different levels of training, especially at the primary level, including empowerment of the public, is a necessity.

\section{A FRAMEWORK FOR TRANSFORMATION}

Burton Clarke's well-known statement is taken as a basic point of departure: "... higher education is the repository of advanced knowledge; research creates it, scholarship preserves, refines and modifies it, teaching disseminates it and professional services use it in developing the wider community" (NCHE, 1996:129). This forms a holistic framework for the principles of transformation.

\section{Principles of Transformation}

* Teaching, research and service delivery are inherently interlinked and thus interdependent elements of the model.

* The needs of the stakeholders/clients form the basic premise upon which training, research and service is built.

* Teaching in speech-language therapy and audiology should comply with higher education policy as laid down by the National Council on Higher Education (NCHE).

* Research should be relevant, implementing where possible a participative action methodology in order to take into account the needs of the country and the stakeholders in particular.

* Service should be available, accessible, accountable, efficient and effective, complying with policy as laid down for all health care professions.

These principles can be applied in the process of transformation in teaching, research and comprehensive service delivery in communication pathology. This view is presented in Table 1.

Speech-language therapists and audiologists "... have by necessity expanded their roles so that they are not only service providers, but also managers of service delivery" (ASHA, 1996:21). Table 1 indicates that the transformed structures ensure goal-directed professional management and service, aiming at satisfying the needs of the communicatively impaired population. Teaching should thus anticipate and react to the needs of the clients, while research should develop new knowledge to improve teaching, as well as advance the efficacy and quality of service delivery. The model also allows for a comprehensive service at all levels.

\section{Transformation in teaching}

Directions for a paradigm shift in higher education are provided by the decision-making bodies of the unified education system, the Professional Board for SpeechLanguage Therapy and Audiology, the changing student 
Table I: Training, research and service delivery

\begin{tabular}{|c|c|c|c|c|}
\hline LEVELS & $\begin{array}{l}\text { PROFESSIONAL } \\
\text { CATEGORIES }\end{array}$ & TEACHING & RESEARCH & $\begin{array}{l}\text { PLACEMENT } \\
\text { \& SERVICE }\end{array}$ \\
\hline Quaternary level & $\begin{array}{l}\text { Specialist: } \\
\text { Speech-Language } \\
\text { Pathology Specialist } \\
\text { Audiology Specialist }\end{array}$ & $\begin{array}{l}\text { University: } \\
\text { Post-graduate } \\
\text { specialisation } \\
\text { Master's and } \\
\text { Doctoral degrees }\end{array}$ & $\begin{array}{l}\text { Contribution of new } \\
\text { knowledge to science } \\
\text { through basic and } \\
\text { developmental } \\
\text { research }\end{array}$ & $\begin{array}{l}\text { Central: Institutions, } \\
\text { Hospitals, Clinics } \\
\text { Consultation and } \\
\text { specialised service }\end{array}$ \\
\hline Tertiary level & $\begin{array}{l}\text { Professional: } \\
\text { Speech-Language } \\
\text { Therapist and } \\
\text { Audiologist }\end{array}$ & $\begin{array}{l}\text { University: } \\
\text { Generalist } \\
\text { Bachelor's degree } \\
\text { (4 years) }\end{array}$ & $\begin{array}{l}\text { Contribution to health } \\
\text { care professions and } \\
\text { improvement of } \\
\text { service delivery } \\
\text { through applied } \\
\text { research }\end{array}$ & $\begin{array}{l}\text { Central, District \& } \\
\text { Communities } \\
\text { Supervision, } \\
\text { Assessment, } \\
\text { Diagnosis, } \\
\text { Treatment \& Training }\end{array}$ \\
\hline Secondary level & $\begin{array}{l}\text { Support personnel: } \\
\text { Speech-Language- } \\
\text { Hearing Therapy } \\
\text { Assistant } \\
\text { Community Speech } \\
\text { and Hearing Worker } \\
\text { (Under direct } \\
\text { supervision) }\end{array}$ & $\begin{array}{l}\text { Technikon/University/ } \\
\text { Institutions } \\
\text { Diploma ( } 2 / 3 \text { years) } \\
\text { Diploma ( } 3 \text { years) } \\
\text { (Accredited by } \\
\text { university/technikon) }\end{array}$ & $\begin{array}{l}\text { Assistance in all } \\
\text { research endeavours } \\
\text { through field work }\end{array}$ & $\begin{array}{l}\text { Central, District \& } \\
\text { Communities } \\
\text { Basic assessment \& } \\
\text { therapy }\end{array}$ \\
\hline Primary level & $\begin{array}{l}\text { Support personnel: } \\
\text { Community } \\
\text { Rehabilitation } \\
\text { Worker/Facilitator } \\
\text { (Speech and Hearing) } \\
\text { (Under supervision } \\
\text { and/or in consultation) }\end{array}$ & $\begin{array}{l}\text { Community } \\
\text { Hospital/Clinic: } \\
\text { Certificate (I year) } \\
\text { (Accredited by } \\
\text { controlling bodies) }\end{array}$ & $\begin{array}{l}\text { Assistance in all } \\
\text { research endeavours } \\
\text { through field work }\end{array}$ & $\begin{array}{l}\text { Communities } \\
\text { Identification, } \\
\text { Community } \\
\text { facilitation, } \\
\text { education and } \\
\text { empowerment, } \\
\text { Referral }\end{array}$ \\
\hline
\end{tabular}

corps, the subject content, the structure of teaching programmes, and the teaching methodologies.

As already indicated by the need for transformation, the principles of transformation as recommended by the NCHE (1996:6-8) have a number of implications for teaching speech-language therapists and audiologists:

* Increased participation implies that greater numbers of students should be recruited from a broader distribution of social groups and classes, that the composition of the student body should change, that programmes, curriculums and qualifications should be diversified, making the introduction of multiple entry and exit points possible. Furthermore new relations between the study and workplace should be introduced, implementing, where necessary, a distance learning methodology. Greater responsiveness has the implication that a shift to a more open and interactive higher education system, engaging with the problems and challenges of its social context, and offering a greater mix of programmes, including those based on the development of vocationally-based competencies and skills needed in the workplace, can become a reality. Especially with higher education becoming more sensitive to societal interests and needs.

* Increased co-operation and partnerships between universities, technikons, non-governmental organi- sations, and other stakeholders imply that relevant, goal-directed and transparent teaching programmes should be instituted, within which mobility and articulation will lead to life-long learning. It seems imperative that life-long learning should be based on a problem-solving teaching methodology.

Professional programmes at the higher education level should prepare the professional of the future (the student of today) to meet the needs of South Africa, while still maintaining the scientific and professional standards of the international market. Cooper (1995:54) states that the future will present challenges such as "... diverse populations to serve, harsh economic and social realities, new technology, expanding scope of practice and new perceptions of our professional roles". These challenges demand an attitudinal change to the science underpinning the profession of speech-language therapy and audiology from primarily an academic discipline, to an important human service profession. Self-regulatory quality enhancement systems, and eventual accreditation of programmes will ensure the relevancy, effectiveness and accountability of these programmes.

In conjunction with the development in quality assurance, changes in the binary system of higher education require greater mobility between the educational offerings of technikons and universities. Curricula, that will enable 
students to upgrade their qualifications by articulating from one institution to the next, and/or from a certificate course, through a diploma course, to a degree course, are needed.

Reflecting this vision, the NCHE recommends that curriculum development should be based on outcomes or competencies. Traditionally curricula were developed in terms of subject matter organised according to disciplinary concepts. Such an approach tended to be historical rather than future orientated, and teacher, rather that student-centred.

The concept of life-long learning embedded in competencybased programmes, is explained by Chambers (1993:791): "Education is a path - not a destination and not the accumulation of nuggets of knowledge or repertoire of skills. Competency represents the point along this path where the learner understands the foundation of his or her skills and has internalized appropriate professional values to work independently in normal settings and manage his or her own continued growth". When qualifying (exit level), a student should be able to demonstrate specified levels of skills, knowledge and understanding, i.e. competencies. These competencies will be regarded as prerequisites for further learning (entrance level to an advanced course). Within this framework the advantages of a modular system becomes apparent.

Adaptation of teaching methodologies becomes a challenge to higher education staff. Life-long learning requires a problem-solving methodology. Added to this challenge, teachers should become sensitive to the needs of the multicultural, multilingual student population, who must eventually take the responsibility for their own further educational development.
Transformation in teaching is presented in Figure 1. This model aims at the development of the health care professional from a beginner, through novice, competent and proficient, to the level of the expert. Thus it caters for the principle of life-long learning, laddering, and mobility. As it is based on the needs of the disabled community, and uses a problem-solving methodology, the approach should ensure effective, relevant and professional service to the client.

\section{Transformation in research}

In the field of research as an adjunct to teaching and service, innovation has become a necessity. "New forms of transdisciplinary knowledge production, the involvement of other research agents in addition to academic researchers... accountability to external constituencies... interaction with knowledge producers in other organisations and enterprises... greater social accountability towards the client/consumer... (and) increased responsiveness and accountability (with regard to) relevance, but not necessarily to short-term problems and demands" (NCHE, 1996:7) are advocated. At the higher education level a sense of the more universal wide-ranging role of knowledge within human affairs should be retained. Research endeavours should never be reduced only to the market and social environment.

New directions in research relate to responsibility and commitment - an ethical orientation. "The Commission on Health Research for Development identified research as the key to equity in development and recommended that each country undertake Essential National Health Research" (ENHR, 1991:1). Two complementary kinds of research efforts are included, viz. country specific, and global research.

\section{Figure I: A Model for Teaching in the Health Care Professions}

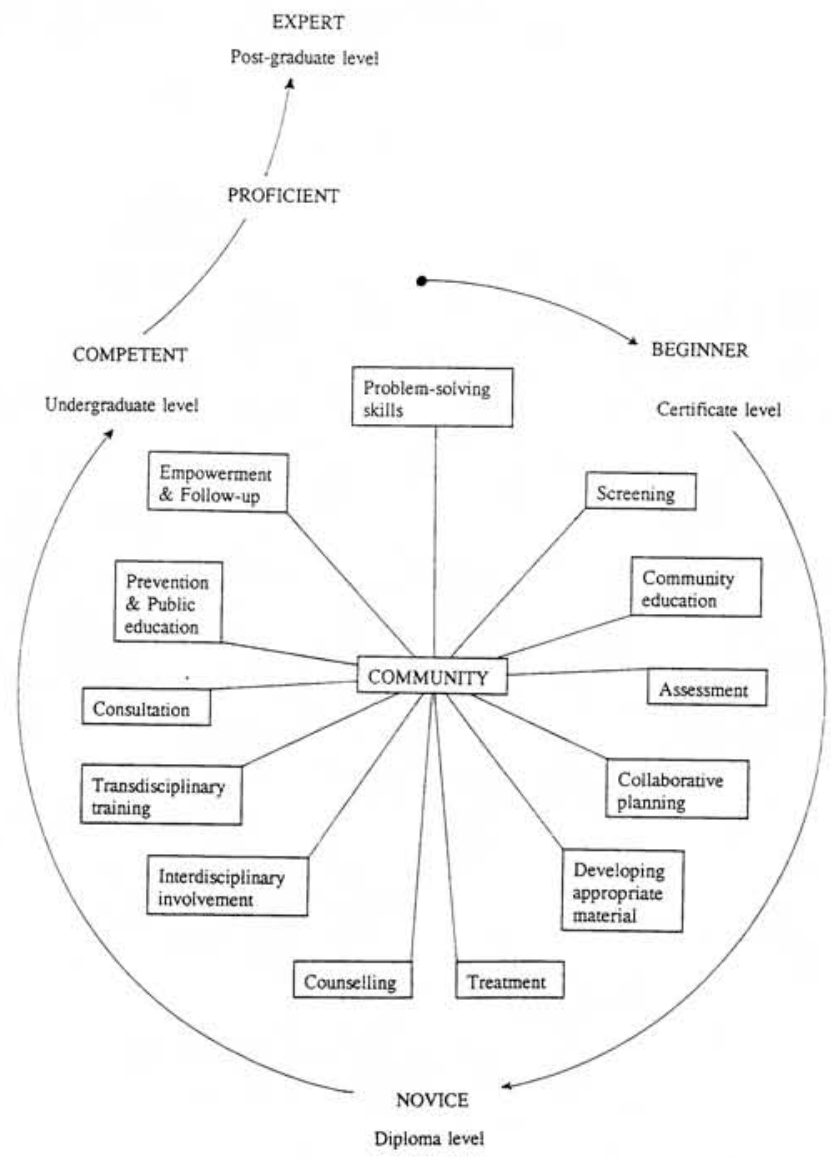


Country specific research strategies aim at the generation of "problem-solving and action-orientated research programs that will tap the skills and knowledge of scientists from a wide range of disciplines" (ENHR, 1991:9).

In formulating a research policy in the higher education sector of South Africa Whiston (1994) states that in this country and at this time researchers have a specific ethical responsibility to carry out relevant and effective research. He phrases it in terms of a paradox and a challenge. "South Africa has the needs of a developing country whilst at the same time she possesses the potential and reach of a developed nation. The bridging of those two cultures could be miraculous if achieved. An example to the world...The challenge is to meet... demands with efficiency, effectiveness and social purpose; ;.. increase social accountability ... environmental and social sustainability" (Whiston, 1994:234). extent the traditional vision was that only a select few, highly qualified professionals were entitled to deliver the service. This framework can be defended, as the safety of the public was thus secured. Unfortunately, within this allor-nothing approach the vast majority of the population did not receive any service at all, while professionals spent much of their time delivering services that competent personnel, after shorter periods of training can handle.

The time has come for highly qualified professionals to stop guarding the boundaries of their professions. This does not imply that the public will be exposed to unsafe practices. It does, however, imply that the health services should be restructured.

Although specialist intervention in communication pathology can never be ignored or underestimated, the

\section{Figure 2: Participatory Research in the Health Care Professions}

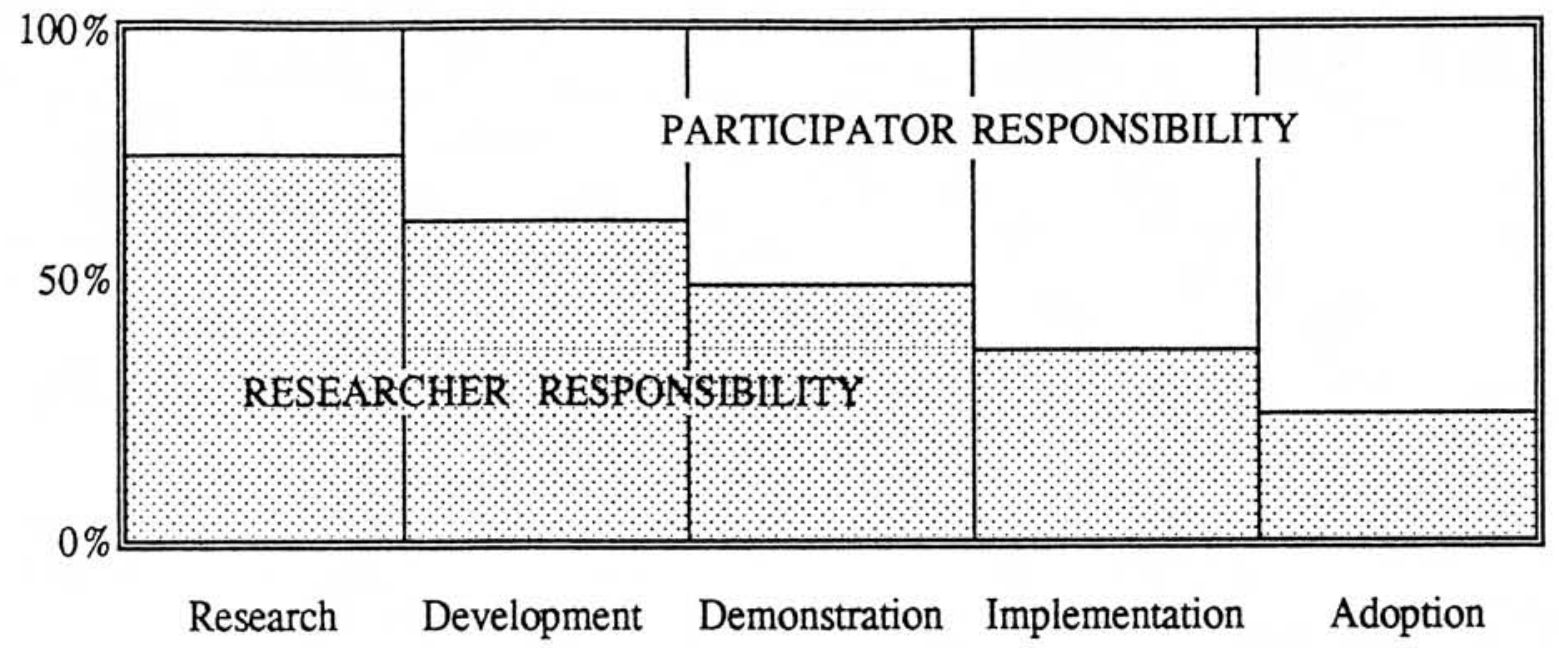

(Adapted from: Powell, Finitzo-Hieber, Friel-Patti, Henderson, 1989)

It is within the framework of shared responsibility and participation (De Koning and Martin, 1996) that Figure 2 is presented.

Participation, especially in applied research and research underlying policy-making and strategic planning, ensures transparency and credibility. As indicated in Figure 2, participation takes place at all levels during the process of research, through dissemination to adoption. Although there seems to be a dividing line between the involvement of the researcher and the partners, this is only hypothetical and indicative of the amount of involvement of each. In actual fact collaboration and co-operation should take place throughout.

In the case of health care research, the partners might well be any one, or a number of the following: disabled persons, parents/caregivers, communities, institutions (universities, technikons, hospitals, schools, clinics), industry, legal organisations, professional groups, non-governmental and government organisations.

\section{Transformation in service delivery}

In the transformation of communication pathology, the most radical paradigm shift has to take place in the field of service delivery. The delivery of a health service to all who need it forms the basis for teaching and research. To a large professions of speech-language therapy and audiology are committed to Primary Health Care (PHC) as defined at Alma Ata as "... an essential health care based on practical, scientifically sound, and socially acceptable methods and techniques, made universally accessible to individuals and families in the community, through their full participation, and at the cost the community and country can afford, to maintain at every stage of their development, in the spirit of self-reliance and self-determination. It forms an integral part, both of the country's health system of which it is the central function and main focus, and of the overall social and economic development of the community. It is the first level of contact of individuals, the family, and community, with the national health system, bringing health care as close as possible to where people live and work, and constitutes the element of a continuing health care process" (Uys, 1996:unnumbered).

The principles of primary health care encompass promotive, preventive, curative and rehabilitative service, operational at all levels of health care. It also implies the acceptance of the principle of community based rehabilitation (CBR). In essence CBR is seen as "a comprehensive approach encompassing disability prevention, rehabilitation in primary health care activities, the integration of disabled children in ordinary schools and the 
provision of opportunities for gainful economic activities for disabled adults" (ILO, UNESCO, WHO, 1994:unnumbered). The shift from institution-based to communitybased service emphasises strategies that were previously regarded as of secondary importance, such as the institution of preventive programmes, community education, and the provision of rehabilitation through group participation.

Another important change in service delivery develops out of the change in teaching curricula and the pursuance of learning outcomes. Discipline restricted skills are exchanged for real-life context skills, transcending the disciplinary boundaries. Professional expertise must be complemented by transdisciplinary rehabilitation. The following figure proposes how health care professions can deliver service in a meaningful way.

As indicated in this Figure, the service delivery system cannot function any longer as a system unrelated to teaching (formal, nonformal and informal education), and research. Practitioners will further need to commit themselves to active participation in the management of the profession, consultative and supervisory endeavours in order to establish a unitary system within which not only service to the disabled, but life-long learning is provided for all levels of health care workers.

\section{CONCLUSIONS}

There is little doubt that the field of communication pathology has undergone enormous changes over the last few decades. Most of these changes have been beneficial, but some core issues have never been addressed, leaving us with no other option than radical transformation. In this article models for transformation in teaching, research and service delivery have been put forward, realising that this is only the beginning of a long and arduous process of implementing and applying these ideas in order to create a new profession which will cater for the needs of a new South Africa.

It is never easy to venture into the unknown, but as in purposeful and goal-directed selling, we have to teach the buyer of these ideas to take off his old clothes before he can step into the new. Often the difficulty does not lie in the new ideas, but in the ability and willingness to escape from the old ones - in this case to renounce the often impractical and irrelevant, for models and strategies which promise to be appropriate and applicable within the South African context.

Figure 3: A Service Model for the Health Care Professions

\begin{tabular}{|c|c|c|c|c|}
\hline & \multicolumn{4}{|c|}{ EDUCATION $\longleftrightarrow$ INTERVENTION } \\
\hline \multirow[t]{2}{*}{ Aims } & Formal & Non- \& Informal & Institutional & Community \\
\hline & Programmes & Programmes & Orientarion & Orientation \\
\hline \multirow[t]{2}{*}{ Focus } & Demand-based & Needs-based & Demand-based & Needs-based \\
\hline & & $\begin{array}{l}\text { Community } \\
\text { Participation }\end{array}$ & & Community \\
\hline \multirow[t]{11}{*}{ Methods } & $\begin{array}{l}\text { Certificate } \\
\text { Programmes }\end{array}$ & $\begin{array}{l}\text { Public } \\
\text { Education }\end{array}$ & $\begin{array}{l}\text { Context-based } \\
\text { support }\end{array}$ & $\begin{array}{l}\text { Assessment } \\
\text { Consultation }\end{array}$ \\
\hline & Diploma & & Primary \& & Enrichment \\
\hline & Programmes & Enrichment & Specialist & Empowerment \\
\hline & & Programmes & Intervention & \\
\hline & Graduate \& & & & \\
\hline & Post-graduate & & & \\
\hline & Programmes & Skills & Consultation & Support \& \\
\hline & & Training & Nerworking & Follow-up \\
\hline & Transdisciplinary & & & \\
\hline & Training & & & \\
\hline & Research & Participation & Research & Participation \\
\hline \multirow[t]{4}{*}{ Ateas } & Institutions & Urban & Communiry & Urhan ${ }^{\top}$ \\
\hline & Technikons & Semi-urban & institutions, & Semi-urban \\
\hline & Universities & Rural areas & Organisations & Rural areas \\
\hline & & $\begin{array}{l}\text { Private practice, } \\
\text { Infrastructures }\end{array}$ & & \\
\hline
\end{tabular}




\section{REFERENCES}

AMERICAN SPEECH-LANGUAGE-HEARINGASSOCIATION 1996: Guidelines for the training, credentialing, use,and supervision of speech-language pathology assistants. ASHA. Supplement 16:21-34.

BEUKELMAN, DR \& GARRETT, KL 1988: Augmentative and alternative communication for adults with acquired severe communication disorders. Augmentative and Alternative Communication, 4:104121.

CHAMBERS. DW 1993: The challenges of modularization. Innovations in Education and Training International, 32 (2): 96-105.

COOPER, CS 1995: Untitled comments on the future. ASHA, 1:55.

DE KONING, K \& MARTIN, M (Eds.) 1996: Participatory Research in Health. Johannesburg: National Progressive Primary Health Care Network.

DEPARTMENT OF NATIONAL HEALTH AND POPULATION DEVELOPMENT 1987: Disability in the Republic of South Africa. Main Report, 1. Department of National Health and Population Development: Pretoria.

ILO, UNESCO, WHO 1994: Community-Based Rehabilitation. Joint Position Paper. International Labour Organization, United Nations
Educational Scientific and Cultural Organization, World Health Organization.

NATIONAL COMMISSION ON HIGHER EDUCATION 1996: NCHE: A Framework for Transformation. Parow: CTP Book Printers.

POWELL, F, Finitzo-Hieber, T, Friel-Patti, S, Henderson, D 1989 : Education of the Healing Impaired Child. San Diego: College-Hill Press.

Rieber, RW \& BRUBAKER, RS 1966: Speech Pathology. Amsterdam: North-Holland Publ. Co.

TASKFORCE ON HEALTH RESEARCH FOR DEVELOPMENT 1991: Essential National Health Research. A Strategy for Action in Health and Human Development. Switzerland.

UYS, IC 1996: The role of the health care professions in primary health care and the reconstruction and development programme. Unpublished document. Professional Board for Speech-Language Therapy and Audiology, South African Medical and Dental Council.

WHISTON, TG 1994: Research Policy in the Higher Education Sector of South Africa. Pretoria: Foundation for Research Development. 